Cell Research (2000),10, 71-77

\title{
Using a non-radioisotopic, quantitative TRAP-based me- thod detecting telomerase activities in human hepatoma cells
}

\author{
Zhang Ru Gang, Xing Wang Wang, Jin Hui Yuan, Li Xia \\ Guo, Hong XIE* \\ Shanghai Institute of Cell Biology, Chinese Academy of Sciences, \\ Shanghai 200031, China
}

\begin{abstract}
A non-radioisotopic, quantitative TRAP-based telomerase activity assay was established mainly by using SYBR Green-I staining instead of radioisotope. Comparing with conventional radioisotope based method, it was better in reproducibility and accuracy. Using this method, we found telomerase activities were absent in normal human liver cells, while detected in all of four human hepatoma cell lines (BEL-7404, SMMC-7721, QGY-7903 and HCCM) without significant differences.
\end{abstract}
Key words: Telomerase, non-radioisotopic telomerase assay, human liver cells, human hepatoma cells.

\section{INTRODUCTION}

Telomerase is a ribonucleoprotein complex that plays a critical role in telomere maintenance and cellular immortality. Telomerase has been considered as tumor diagnostic marker and potential target for cancer therapy[1], [2]. A sensitive, reliable and quantitative assay is of high interest in this field. The development of a very sensitive Telomeric Repeat Amplification Protocol (TRAP) for measuring telomerase activity in cell extracts has been proved to be an important tool for understanding the role of telomerase[3]. However, a peculiar artifact was described which in part results from a staggered annealing between the elongated TS primer and the reverse primer CX[4]. To eliminate the described artifact, a 6 bp anchor (5' -GCGCGG-3') was added to the 5 ' -end of CX, and it was called ACX[5]. Although a number of improvements to the

\footnotetext{
* Corresponding author. E-mail: xiehong@sunm.shcnc.ac.cn
} 
Non-radioisotopic telomerase activities in human hepatoma cells

original TRAP assay have been done, radioisotope has been used in almost all modified methods[6]. In the present study, we reported the establishment of a non-radioisotopic telomerase assay which increased reliability, and allowed the expression of relative levels and identification of the presence of inhibitors of Taq polymerase at the same time.

Liver cancer was one of the most common malignant abnormalities in China, but systematic studies on the relationship between telomerase and liver cancer have not been reported. As the first step of our research, we analyzed the expression levels of telomerase activity in human normal liver cells and four human hepatoma cell lines (BEL-7404, SMMC-7721, QGY-7903 and HCCM).

\section{MATERIALS AND METHODS}

\section{Cells and culture condition}

BEL-7404, SMMC-7721, and QGY-7903 human hepatoma cell lines from Cell Bank of Chinese Academy of Sciences, HCCM as a gift from Dr. XIE Yong at HongKong University of Science and Technology[7]. Human normal liver cells derived from normal human liver tissue was the gift of Dr. CHANG Yun-Chao in our Institute. Cells were cultured in RPMI-1640 medium (Gibco) supplemented with $10 \%$ heat-inactivated new-born calf serum, at $37^{\circ} \mathrm{C}$ in a humidified $\mathrm{CO}_{2}$ incubator containing $5 \% \mathrm{CO}_{2}$ and $95 \%$ air.

\section{Preparation of cell extracts}

Cells were washed twice in cooled PBS ( $\mathrm{pH}$ 7.4) and homogenized in ice-cold lysis buffer [10 mM Tris- $\mathrm{HCl}$ (pH 7.5), $1 \mathrm{mM} \mathrm{MgCl2,} 1 \mathrm{mM}$ EGTA, $0.1 \mathrm{mM}$ PMSF, $5 \mathrm{mM} \beta$-mercaptoethnol, $0.5 \%$ CHAPS (Sigma), 10\% glycerol (v/v)].

After $30 \mathrm{~min}$ on ice, the lysates were centrifuged at $12,000 \mathrm{~g}$ for $30 \mathrm{~min}$ at $4^{\circ} \mathrm{C}$, and the supernatant was rapidly frozen and stored at $-80^{\circ} \mathrm{C}$. The concentration of protein was measured with Bradford protein assay, an aliquot of extract containing $1 \mathrm{mg}$ of protein being used for each telomerase assay[3].

\section{Telomerase activity assay}

Radioisotope labeled method (RL method)

The method was performed as described[3] with some modifications in primers and PCR conditions. Briefly, an aliquot of $1 \mathrm{mg}$ TS substrate primer (5'-AATCCGTCGAGCAGAGTT-3'), was end-labeled by 5 units T4 polynucleotides kinase (Promega) and $2.5 \mu \mathrm{Ci}$ of $1.5 \mathrm{GBq} / \mathrm{ml}\left[\gamma^{-32} \mathrm{P}\right]$ ATP(Amersham Pharmacia) in $10 \mu \mathrm{l}$ reaction mix. The kinase reaction mixture was incubated at $37^{\circ} \mathrm{C}$ for $20 \mathrm{~min}$, and then heat inactivated at $95^{\circ} \mathrm{C}$ for $5 \mathrm{~min}[8]$. The cell extract was incubated in $50 \mathrm{ml}$ of TRAP reaction buffer containing $20 \mathrm{mM}$ Tris- $\mathrm{HCl}(\mathrm{pH} 8.3), 1.5 \mathrm{mM} \mathrm{MgCl}{ }_{2}, 63 \mathrm{mM} \mathrm{KCl}, 0$. 005\% Tween-20, $1 \mathrm{mM}$ EGTA, $50 \mathrm{mM}$ of each dNTPs, $1 \mu \mathrm{g}$ T4g32 protein (Boehringer Mannheim), $0.1 \mu \mathrm{g} / \mathrm{ml} \mathrm{BSA}$ and $0.1 \mu \mathrm{g} 5^{\prime}$ end-labeled TS. After a $30 \mathrm{~min}$ incubation at $30{ }^{\circ} \mathrm{C}$ for telomerasemediated extension of the primer, $0.1 \mu \mathrm{g}$ of return primer ACX(5'-GCGCGG[CTTACC] ${ }_{3}$ CTAACC3'), $0.1 \mathrm{mg}$ internal control primer NT (5'-ATCGCTTCTCGGCCTTTT-3'), $0.01 \mathrm{aM}$ of the internal control template TSNT(5'-AATCCGTCGAGCAGAGTTAAAAGGCCGAGAAGCGAT-3') and 2 units Taq DNA polymerase (Promega) were added. The reaction mixture was then subjected to PCR in a thermal cycler (Perkin-Elmer 2400) with 30 cycles at $94^{\circ} \mathrm{C}$ for $30 \mathrm{~s}, 60^{\circ} \mathrm{C}$ for $30 \mathrm{~s}$, then one cycle of extension at $72^{\circ} \mathrm{C}$ for $10 \mathrm{~min}[5]$. The PCR products were resolved by electrophoresis in a $15 \%$ polyacrylamide gel under nondenaturing conditions. The banding pattern was visualized by autoradiography for $12 \mathrm{~h}$ and analyzed by Gelworks 1D advanced software in Shanghai Institute of Biochemistry, Chinese Academy of Sciences. 
Zhang RG et al.

Non-radioisotopic method (NR method)

The method newly established by us was performed as follows: The cell extract was incubated in $50 \mu \mathrm{l}$ of TRAP reaction buffer containing $20 \mathrm{mM}$ Tris- $\mathrm{HCl}$ ( $\mathrm{pH} 8.3$ ), $1.5 \mathrm{mM} \mathrm{MgCl} 2,63 \mathrm{mM} \mathrm{KCl}$, $0.005 \%$ Tween-20, $1 \mathrm{mM}$ EGTA, $50 \mu M$ of each dNTPs and $0.1 \mu \mathrm{g}$ TS. After a $30 \mathrm{~min}$ incubation at $30^{\circ} \mathrm{C}, 0.1 \mu \mathrm{g}$ ACX, $0.1 \mu \mathrm{g} \mathrm{NT}, 0.003 \mathrm{amol}$ TSNT and 2 units Taq DNA polymerase were added. The reaction mixture was then subjected to PCR amplication with same cycle running as in RL method. The PCR products were resolved by electrophoresis in a $12 \%$ polyacrylamide gel under nondenaturing conditions. The gel was then stained with SYBR Green-I (FMC Bioproducts) for 15 min, visualized by UVP system and analyzed by Gelworks 1D advanced software.

For RNase treatment, the extracts were incubated with $5 \mathrm{mg} / \mathrm{ml} \mathrm{RNase}$ A for $20 \mathrm{~min}$ at $37^{\circ} \mathrm{C}$. Heat inactivation was performed by heating the extracts at $75^{\circ} \mathrm{C}$ for $15 \mathrm{~min}$. In every experiment, a negative control ( $1 \mu \mathrm{l}$ CHAPS lysis buffer) and 0.1 amol of the quantification standard oligonucleotide R8(5'-AATCCGTCGAGCAGAGTTAG[GGTTAG] ${ }_{7} 3$ ') were included. All experiments were repeated at least twice.

The amount of telomerase activity was expressed as total product generated (TPG) by using the formula: $\mathrm{TPG}=\{[(\mathrm{TP}-\mathrm{B}) / \mathrm{TI}] /[\mathrm{R} 8-\mathrm{B}] / \mathrm{RI}\} \times 100$. In the formula, TP, B, R8, TI and RI were telomerase products in fluorescent or radio counts from the test extract, blank lysis buffer only, R8 quantification standard, and internal controls of the test extract and that of the R8 quantification standard respectively.

\section{RESULTS AND DISCCUSION}

\section{Establishment of NR method}

Products of telomerase activity in BEL-7404 human hepatoma cells started at $50 \mathrm{bp}$ and displayed 6 bp periodicity (Fig 1, Lane 3). Primer dimer PCR artifacts derived from TS and reverse primer CX used previously were indistingishable from the genuine telomerase

Fig 1.

Control experiments confirming the specificity of telomerase activity assay in cell extracts of BEL-7404 human hepatoma cells. Lane 1: negative lysis buffer control Lane 2: $\mathrm{R}_{8}$ quantification standard

Lane 3: telomerase activity in the extracts of BEL-7404 cells

Lane 4: telomerase activity in the extracts treated with RNase A

Lane 5: telomerase activity in heat inactivated extracts

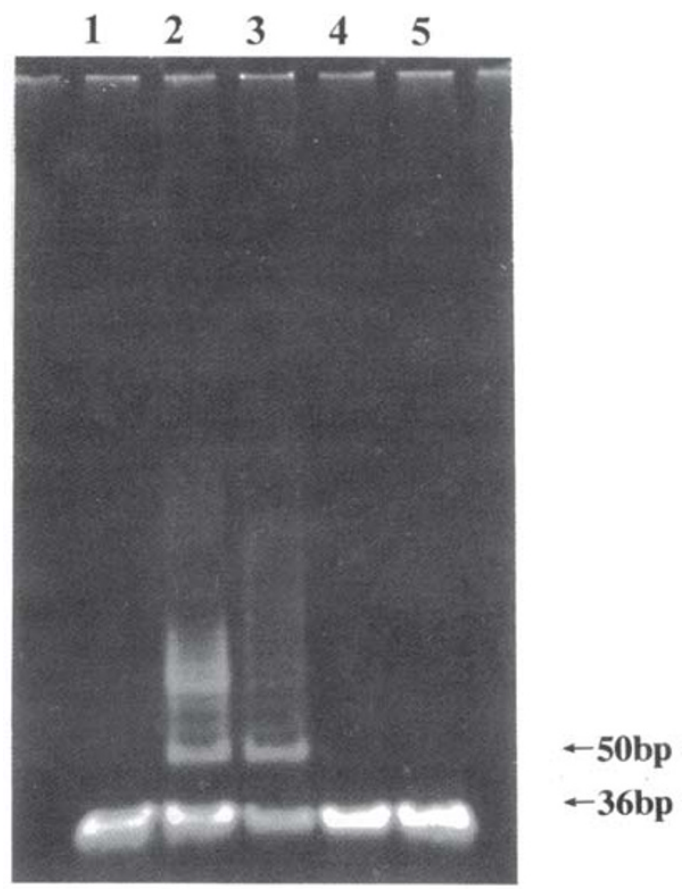


Non-radioisotopic telomerase activities in human hepatoma cells

products. However, the primer dimer PCR artifacts, derived from TS and ACX reverse primers used now without 6 bp periodicity, could be easily distingushed from the telomerase products. Several control experiments were done as well. The specificity of telomerase activity detected by NR method was confirmed by the disappearance of specific TRAP products upon treatment of RNase and heat (Fig 1, Lane 4, 5). Substitution of cell extracts with lysis buffer also did not result in the synthesis of specific TRAP products (Fig 1, Lane 1).

The $R_{8}$ quantification standard oligonucleotide exhibited a characteristic pattern

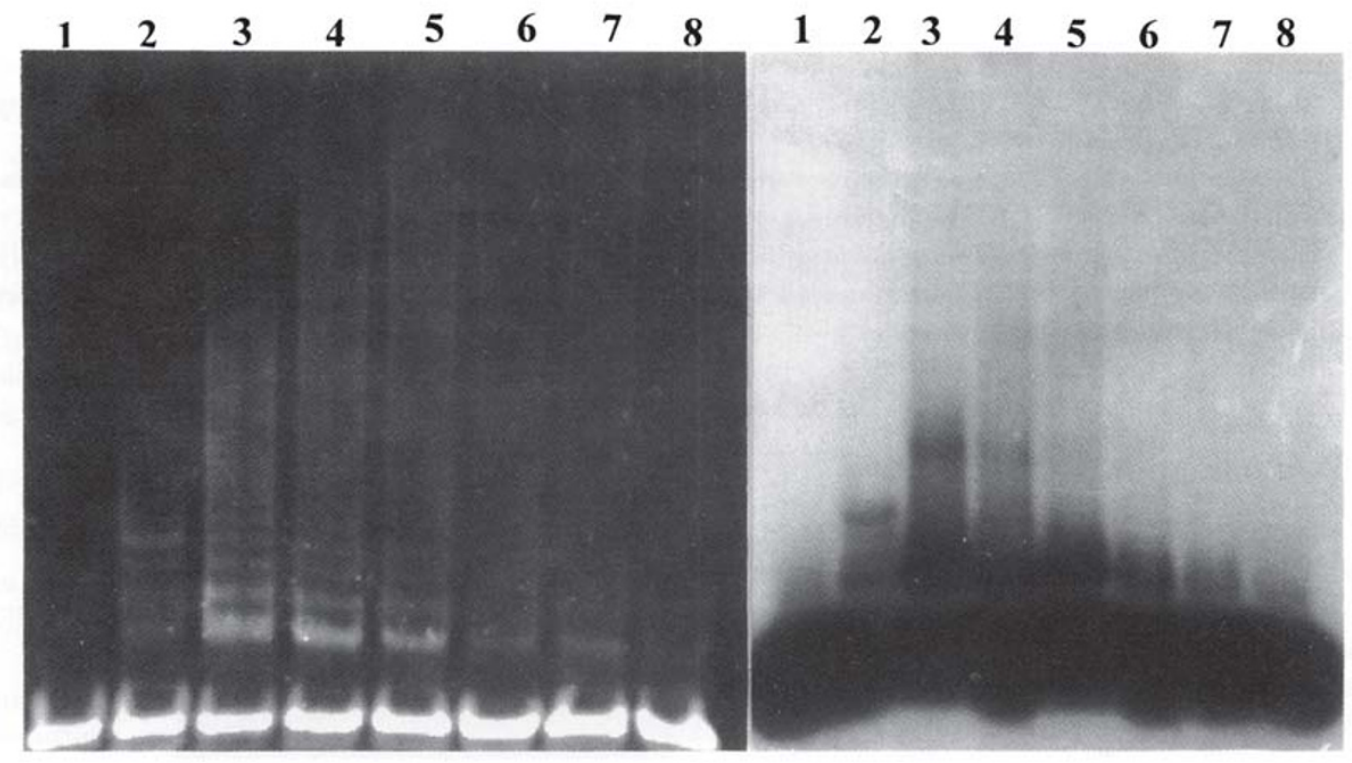

A

B

Fig 2.

Sensitivity comparison between NR method and RL method by using extracts of SMMC-7721 human hepatoma cells.

A: results of NR method.

Lane 1: negative lysis buffer control

Lane 2: R8 quantification standard

Lane 3: 2500 cells

Lane 4: 1000 cells

Lane 5: 500 cells

Lane 6: 100 cells

Lane 7: 50 cells

Lane 8: 10 cells

B: results of $\mathrm{RL}$ method.

Lane 1: negative lysis buffer control

Lane 2: R8 quantification standard

Lane 3: 2500 cells

Lane 4: 1000 cells

Lane 5: 500 cells

Lane 6: 100 cells

Lane 7: 50 cells

Lane 8: 10 cells

shown in the first through seventh TRAP products (Fig 1, Lane 2). Utilization of the quantification standard provided a means to express the level of telomerase activity as an 
absolute value. TSNT was an internal control PCR template amplified by TS and NT, giving a 36 bp product. Incorporation of the TRAP internal control was useful in measuring telomerase activity levels in samples that might contain inhibitors of Taq polymerase (Fig 1, Lane 3). By this means, false negative results could be easily identified by the disappearance of the internal control band.

\section{Comparison between NR method and $R L$ method}

As shown in Fig 2, RL method and NR method were about in the same degree of sensitivity, and telomerase activity in extracts from only as few as 10 SMMC-7721 human hepatoma cells could be detected by both methods. The results from three repeated experiments showed that the reproducibility and accuracy of NR method were better than RL method (Fig 3).

There were no effects on telomerase activity detection while omitting the expensive T4g32 protein used in NR method. At the same time, the use of SYBR Green-I was cheaper than $\left[\gamma{ }^{32} \mathrm{P}\right]$-ATP. All of these modifications make the NR method more economical than RL method. In addition, NR method can get quantitative result in one day by easy handling, while RL method needs at least two days.

\section{Fig 3.}

Reproducibility and accuracy comparison between NR method and RL method by using extracts of SMMC-7721 human hepatoma cells.

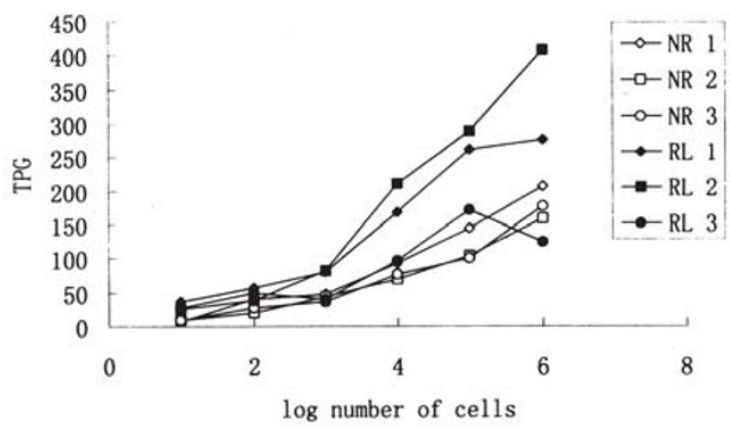

Quantification of telomerase activities in human normal liver cells and different human hepatoma cell lines

In this survey, telomerase activity of four human hepatoma cell lines (BEL-7404, SMMC-7721, QGY-7903 and HCCM) and normal liver cells were examined. All four human hepatoma cell lines showed telomerase activity, whereas human normal liver cells were apparently telomerase negative. The relative telomerase activities of BEL-7404, SMMC-7721, QGY-7903 and HCCM were 75.0, 57.5, 51.1 and 77.3 TPG, respectively (Fig 4). This results indicated that telomerase activity was significant in human hepatoma cells, thus providing a potential approach of selective liver cancer therapy by targeting telomerase activity.

Several researchers showed that the levels of telomerase activity was correlated with 
Non-radioisotopic telomerase activities in human hepatoma cells

tumor stage, metastasis and prognosis of cancer, besides as a marker in tumor diagnosis and a potential target in tumor therapy[1, 2,8,9]. As a result, it is desirable to develop a sensitive, fast, easy handling, reliable and quantitative method in telomerase detection. In this report, we have provided a newly established non-radioisotopic quantitative TRAPbased telomerase assay with obvious advantages. Compared with the radio-labeled method, its reproducibility and accuracy are better. Moreover it is also apparently more convenient in handling. Using this method, we have demonstrated that the telomerase activities are expressed in four human liver carcinoma cell lines but not in normal human liver cells.

Fig 4.

Telomerase activities of human normal liver cells and different human hepatoma cell lines. Lane 1: negative lysis buffer control

Lane 2: $R_{8}$ quantification standard

Lane 3: telomerase activity of human normal liver cells

Lane 4: telomerase activity of BEL-7404 human hepatoma cells

Lane 5: telomerase activity of SMMC-7721 human hepatoma cells

Lane 6: telomerase activity of QGY-7903 human hepatoma cells

Lane 7: telomerase activity of HCCM human hepatoma cells

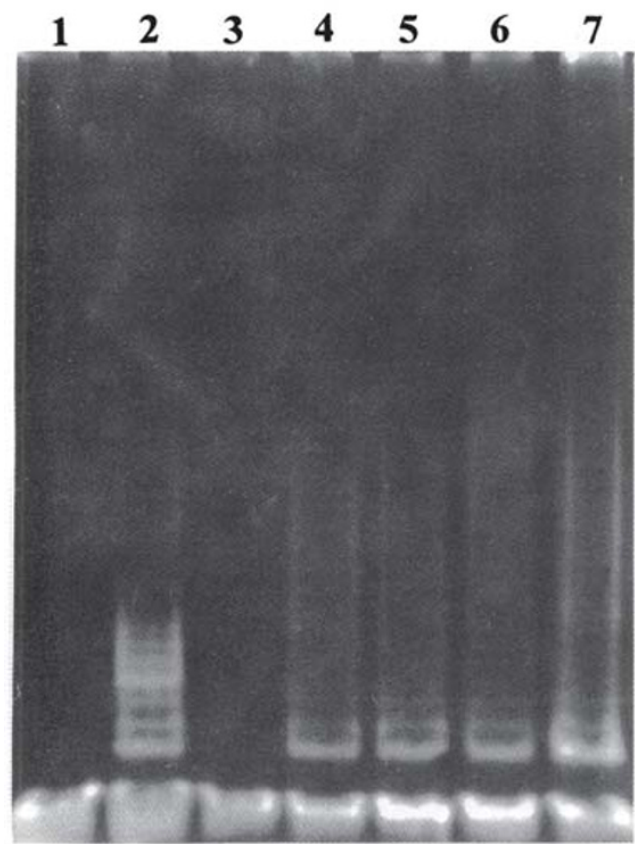

\section{REFERENCES}

[1] Zhang RG, Yuan JH, Xie H. Telomerase and tumor. Chinese Journal of Cell Biology 2000; 22:25-7.

[2] Zhang RG, Yuan JH, Wang XW, Xu B, Xie H. Telomerase: a novel target of antitumor agents. Chinese Journal of Oncology Research. In press.

[3] Kim WK, Piatyszek MA, Prowse KR, et al. Specific association of human telomerase activity with immortal cells and cancer. Science 1994; 266:2011-15.

[4] Krupp G, Kuhne K, Tamm S, et al. Molecular basis of artifacts in the detection of telomerase activity and a modified primer for a more robust 'TRAP' assay. Nucleic Acids Research 1997; 25:919-21.

[5] Kim NW, Wu F. Advances in quantification and characterization of telomerase activity by the telomeric repeat amplification protocol (TRAP). Nucleic Acids Research 1997; 25:2595-7.

[6] Kim NW. Clinical implications of telomerase in cancer. European Journal of Cancer 1997; 33:781-6. 
Zhang RG et al.

[7] Tay N, Chan SH, Ren EC. Detection of integrated hepatitis B virus DNA in hepatocellular carcinoma cell lines by nonradioactive in situ hybridization. Journal of Medical Virology 1990; 30:266-71.

[8] Albanell J, Lonardo F, Rusch V, et al. High telomerase activity in primery lung cancers: association with increased cell proliferation rates and advanced pathologic stage. Journal of the National Cancer Institute 1997; 89:1609-15.

[9] Zhang RG, Yuan JH, Wang XW, Xie H. Inhibition of telomerase activity of BEL-7404 human hepatoma cells by its RNA component antisense oligonucleotides and their effects on cell cycle in vitro. Acta Pharmacologica Sinica. In press.

Received Dec-9-1999. Revised Jan-18-2000. Accepted Jan-21-2000. 